\title{
Electrochemical Generation of Syngas from Water and Carbon Dioxide at Industrially Important Rates
}

\author{
Zengcai Liu ${ }^{a}$, Richard I. Masel ${ }^{a}$, Qingmei Chen ${ }^{a}$, Robert Kutz ${ }^{\text {a }}$, Hongzhou Yang a , Krzysztof \\ Lewinski ${ }^{\text {b }}$, Marina Kaplun ${ }^{b}$, Sean Luopa ${ }^{\text {b }}$, Dale R. Lutz ${ }^{\text {b* }}$ \\ a Dioxide Materials Inc., 3998 FAU Blvd., Suite 300, Boca Raton, FL, 33431, USA \\ b 3M Company, 3M Center, Saint Paul, MN, 55144, USA
}

ABSTRACT:

The electrochemical production of syngas would enable production of chemicals and transportation fuels from carbon dioxide, water and renewable energy, but a suitable process at the moment does not exist. In this paper we consider two options for syngas production: i) $\mathrm{CO}_{2}$ electrolysis to produce $\mathrm{CO}$, water electrolysis to produce $\mathrm{H}_{2}$ and then mixing the $\mathrm{CO}$ and $\mathrm{H}_{2}$ to yield syngas; and ii) the simultaneous coelectrolysis of $\mathrm{CO}_{2}$ and $\mathrm{H}_{2} \mathrm{O}$ in a single electrolyzer. The results show that both processes can produce syngas at industrially important rates. In this paper we demonstrate $\mathrm{CO}_{2}$ electrolysis at $100 \mathrm{~mA} / \mathrm{cm}^{2}$, i.e., about 1100 turnovers/sec, and water electrolysis at $8 \mathrm{~A} / \mathrm{cm}^{2}$ at $2.0 \mathrm{~V} / \mathrm{cell}$, with about 80,000 turnovers/sec. Both systems are stable for a thousand hours or more, i.e., billions of turnovers. We also demonstrate simultaneous $\mathrm{CO}$ and $\mathrm{H}_{2}$ production in a single electrolyzer. These results demonstrate that syngas can be produced at industrially important rates via electrolysis.

KEYWORDS: syngas; electrolyzer; anion exchange membrane; $\mathrm{CO}_{2}$ conversion; carbon dioxide utilization

\section{INTRODUCTION:}

Minimizing the release of carbon dioxide $\left(\mathrm{CO}_{2}\right)$ greenhouse gas to the environment, while still providing the liquid fuels and other hydrocarbons that current civilization relies on, will require the large scale commercialization of processes analogous to photosynthesis. Water and carbon dioxide will need to be combined with renewable energy from carbon-neutral sources, such as wind or solar, to produce hydrocarbons in a sustainable manner [1-10]. Initially, this $\mathrm{CO}_{2}$ will come from high $\mathrm{CO}_{2}$ concentration sources such as steel mills, cement furnaces, and ethanol fermenters. Ultimately, it may become necessary to capture $\mathrm{CO}_{2}$ from ambient atmosphere in order to reduce global concentrations to early industrial levels. Several routes have been discussed in the literature, as summarized in our recent review [10]. In this paper we will discuss a route that we have been exploring: $\mathrm{CO}_{2}$ electrolysis to $\mathrm{CO}$ [10-23], water electrolysis to produce $\mathrm{H}_{2}$ [24-26], or an electrolyzer that simultaneously does both water and $\mathrm{CO}_{2}$ electrolysis. The produced $\mathrm{CO}$ and $\mathrm{H}_{2}$ are either mixed to form syngas or produced directly 
at the desired syngas ratio in a single reactor, so that the syngas can then be converted to fuels and chemicals via well-established industrial processes (such as the Fischer Tropsch [27] process.)

We are not the only group working on this topic. Indeed, our recent review article [10] cited 323 previous literature contributions, and there are several excellent reviews [28-53]. In this paper we wish to review our own work on the topic. One is referred to the review articles [10], [28-53] for descriptions of the work from earlier investigations.

This paper will concentrate on describing two advances. First, we will review our latest work on proton exchange membrane (PEM) water electrolyzers, in which we obtained power densities in excess of $50 \mathrm{~W} / \mathrm{cm}^{2}$ using only $0.25 \mathrm{mg} / \mathrm{cm}^{2}$ of $\mathrm{IrO}_{2}$ as the anode catalyst $[25,28$, 29]. In comparison, present commercial PEM electrolyzers typically use loadings of $4-8 \mathrm{mg} / \mathrm{cm}^{2}$ of Platinum Group Metal (PGM) and achieve much lower power densities [54-58]. Second, we will review our demonstration of electrolysis of $\mathrm{CO}_{2}$ into $\mathrm{CO}$ and $\mathrm{O}_{2}$ with unexpectedly high selectivity and low overpotential at ambient temperature and pressure [10-22]. The latter result is due in part to the unexpected suppression of the competing water electrolysis reaction by the unique organic cationic "Helper Catalysts" employed [10-22].

Both electrolysis processes have been demonstrated at membrane current densities of at least $100 \mathrm{~mA} / \mathrm{cm}^{2}$, which is an industrially relevant rate comparable to that of commercial chlor-alkali electrolyzers.

\section{METHODS}

\section{1 $\quad \mathrm{PEM} \mathrm{H}_{2} \mathrm{O}$ Electrolyzers}

The water electrolysis experiments were performed in $50 \mathrm{~cm}^{2}$ single cell hardware (Fuel Cell Technologies, Albuquerque, New Mexico, USA) using a graphite based quad-serpentine cathode flow field (Poco Graphite, Inc. Decatur, Texas,) and a modified Ti anode quadserpentine flow field (Giner, Inc., Auburndale, Massachusetts, USA). All catalyst coated membranes (CCMs) were a construction of nanostructured thin film (NSTF) electrodes, laminated under suitable conditions of heat and pressure in a purposely built linear high pressure laminator onto a perfluorosulfonic acid (PFSA) polymer electrolyte membrane (3M Company, St. Paul, MN, USA) with a uniform lot of Pt-NSTF cathode electrodes (Pt loading $0.25 \mathrm{mg} \cdot \mathrm{cm}^{-2}$, unless otherwise noted), and the anode electrode as described below. The cells were assembled using in-house prepared CCMs, sintered and platinized Ti gas diffusion layers (GDLs) (Giner, Inc.,) and CHR® (Saint-Gobain Performance Plastics, Merrimack, New Hampshire, USA) Teflon $^{\text {TM }}$ (DuPont, Wilmington, DE, USA) reinforced gaskets. Gasket thickness was adjusted to match the desired cell compression level of the GDLs. All cells were assembled with bolts torqued to $12.5 \mathrm{~N} \cdot \mathrm{m}$. The performance tests were performed on in-house built test stands consisting of a $10 \mathrm{~kW}$ TDK Lambda ESS power supply (Minato-ku, Tokyo, Japan) with a Fluke 45 A voltmeter with 1.0 MHz sampling capability (Everett, Washington, USA), Ismatec IDEX REGLO-CPF Digital pumps (ISM 321) equipped with RH1.CKC pump heads (Cole-Parmer $\mathrm{GmbH}$, Wertheim, Germany), and controlled via in-house developed LabView (National Instruments, Austin, Texas, USA) drivers and control software. Water was fed to cells on the anode side at the rate of $1.25 \mathrm{~cm}^{3} \cdot \mathrm{s}^{-1}$ preheated to $85^{\circ} \mathrm{C}$ to enable a controlled cell temperature of $80{ }^{\circ} \mathrm{C}$. Cell temperature was controlled by Love Controls PID temperature controllers (Dwyer Instruments, Inc., Michigan City, Indiana, USA) and cartridge heaters inserted directly into the cell's body. Polarization curves were run from $1.35 \mathrm{~V} /$ cell to $2.0 \mathrm{~V} /$ cell at $50 \mathrm{mV}$ steps and $300 \mathrm{~s}$ per step. Polarization curves were typically taken every 12 hours, before and after $2.0 \mathrm{~A} \cdot \mathrm{cm}^{-2}$ 
galvanostatic polarizations. Galvanostatic polarizations were performed by holding $100 \mathrm{~A}$ of total current and measuring the voltage response; results shown are the hourly average of this voltage.

\section{$2.2 \quad \mathrm{CO}_{2}$ Electrolyzers}

\subsubsection{Chemicals}

Hydrochloric acid $(\mathrm{HCl})$, sulfuric acid $\left(\mathrm{H}_{2} \mathrm{SO}_{4}\right)$, and two "ionic liquid" salts of the 1-ethyl-3methyl imidazolium $\left(\mathrm{EMIM}^{+}\right)$cation, namely the chloride (EMIM-Cl) and the bisulfate, EMIM$\mathrm{HSO}_{4}$, were purchased from Sigma Aldrich and used as received. The salts EMIM-HCO 3 , $(\mathrm{EMIM})_{2} \mathrm{SO}_{4}$, and EMIM- $\mathrm{H}_{2} \mathrm{PO}_{4}$ were synthesized at $3 \mathrm{M}$ and Dioxide Materials' laboratories by dissolving EMIM-Cl in ethanol, adding $\mathrm{KHCO}_{3}, \mathrm{~K}_{2} \mathrm{SO}_{4}$, or $\mathrm{KH}_{2} \mathrm{PO}_{4}$ in ethanol, filtering off the $\mathrm{KCl}$ precipitate, and then removing the ethanol under vacuum. The ionic liquids were diluted by or dissolved in deionized water (18.2 M , Millipore) with 50 vol. \% (for liquids) or $50 \mathrm{wt}$ \% for solids. $\mathrm{HCl}$ and $\mathrm{H}_{2} \mathrm{SO}_{4}$ were diluted to the desired concentration with deionized water.

\subsubsection{Preparation of electrodes}

A silver (Ag) cathode for $\mathrm{CO}_{2}$ reduction was prepared as follows: A cathode ink is made by mixing $30 \mathrm{mg}$ of catalyst nanoparticles with $0.1 \mathrm{ml}$ deionized water $(18.2 \mathrm{M} \Omega$, Millipore) and $0.2 \mathrm{ml}$ isopropanol (3032-16, Macron). The mixture is then sonicated for 1 minute. The cathode ink is spray painted onto a gas diffusion layer (Sigracet 35 BC GDL, Ion Power) covering an area of $2.5 \mathrm{~cm} \times 2.5 \mathrm{~cm}$. Ag/Ni bimetallic electrodes with different ratios were also prepared for the purpose of syngas production. An $\mathrm{IrO}_{2}$ anode was prepared in a same way.

\subsubsection{Electrochemical testing: liquid cells}

To produce $\mathrm{CO}$ with high selectivity, we conducted the experiments in two types of cell as shown in Figure 1: (a) liquid cell [19]; and (b) solid cell. The liquid cell was assembled as described in Rosen et al. [19], Brushett et al. [59], and Whipple et al. [60] The cell consists of a multicompartment cell. Ag and $\mathrm{IrO}_{2}$ were used as cathode and anode, respectively. The active area was $1 \mathrm{~cm}^{2}$. Various ionic liquids with $\mathrm{EMIM}^{+}$cation and different anions were tested as helper catalysts and fed to the liquid chamber in the cathode. $\mathrm{CO}_{2}$ was fed to the gas chamber in the cathode at $10 \mathrm{sccm}$. $0.5 \mathrm{M} \mathrm{H}_{2} \mathrm{SO}_{4}$ was used as the anolyte and fed to the liquid chamber in the anode. The cell was run at $50 \mathrm{~mA} / \mathrm{cm}^{2}$, and the gas product from cathode was analyzed by gas chromatography (GC.) EMIM-Cl was chosen to study the effect of concentration on the conductivity and the $\mathrm{CO}$ selectivity. The conductivity of EMIM-Cl solution was measured using a conductivity meter. 


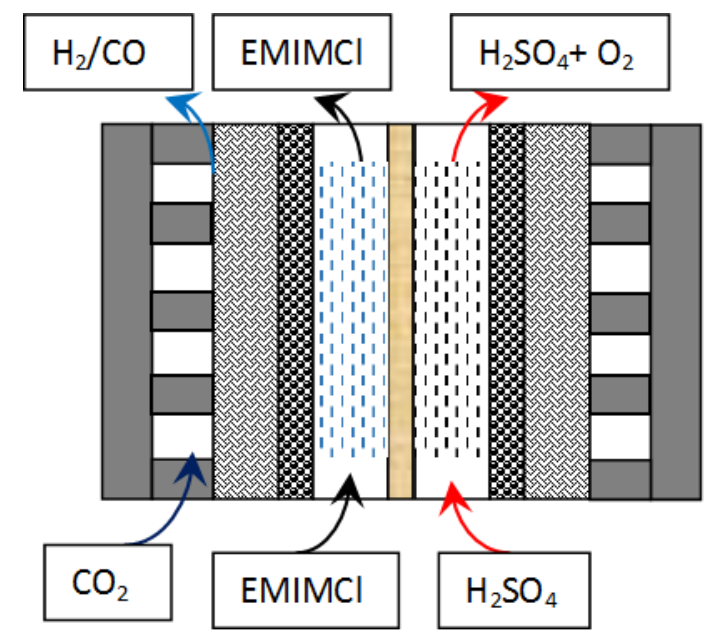

(a) Liquid Electrolyte Cell

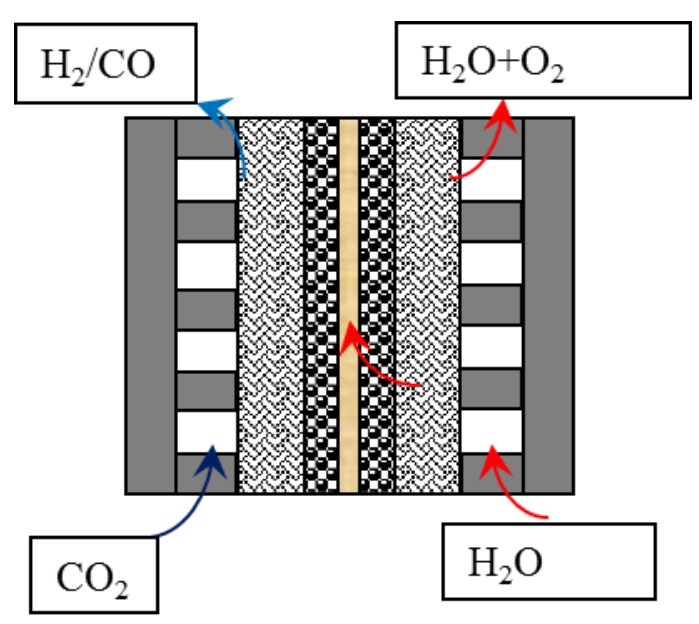

(b) Solid Electrolyte Cell

Figure 1 Schematic of liquid electrolyte cell and solid electrolyte cell [14].

\subsubsection{Electrochemical testing: solid state cells}

The solid cell was assembled by sandwiching a proprietary Dioxide Materials membrane between a silver cathode on carbon paper and an iridium oxide anode on carbon paper with a metal loading of about $2 \mathrm{mg} / \mathrm{cm}^{2}$. The whole assembly was mounted in Fuel Cell Technologies 5 $\mathrm{cm}^{2}$ fuel cell hardware with serpentine flow fields. Water was fed into the anode at a rate of 0.1 sccm, and $\mathrm{CO}_{2}$ was fed to the cathode at $20 \mathrm{sccm}$. A certain current was applied to the cell, and the cell voltage and the $\mathrm{CO}$ selectivity were measured after the cell had been running for 30 minutes.

\subsection{Direct syngas production in a single cell}

In order to produce syngas from the liquid cell (Figure 1a,) we tested the effect of $\mathrm{pH}$ of the EMIM-Cl solution on the $\mathrm{CO}$ selectivity (Figure 4). The $\mathrm{pH}$ of the EMIM-Cl solution was adjusted using $6 \mathrm{M} \mathrm{HCl}$, and the $\mathrm{CO}$ selectivity at $25 \mathrm{~mA} / \mathrm{cm}^{2}$ was determined by GC. Two experiments were designed to produce syngas in a solid cell (Figure 1b). One approach was to use $\mathrm{Ag} / \mathrm{Ni}$ bimetallic catalyst for the cathode while running $\mathrm{H}_{2} \mathrm{O}$ in the anode; the other approach was to run $\mathrm{H}_{2} \mathrm{SO}_{4}$ in the anode while using $\mathrm{Ag}$ as the cathode catalyst.

\section{RESULTS}

\section{1 $\mathrm{H}_{2}$ from water splitting, using proton exchange membrane electrolyzers}

PEM membranes using proton $\left(\mathrm{H}^{+}\right)$conduction have high ionic conductivity, but the PGM catalysts needed for operation in acidic media are expensive, so efforts are made to reduce the necessary catalyst loading. Most recent investigators [55-58, 61-63] have used catalyst loadings above $1 \mathrm{mg} / \mathrm{cm}^{2}$, although there is one recent report using lower loadings [54].

In the work described here we concentrated on electrolyzers with anode catalyst loadings of only $0.25 \mathrm{mg} / \mathrm{cm}^{2}$. The work used proprietary oxygen evolution reaction (OER) catalysts comprised of thin semi-continuous films of iridium catalyst deposited on nanoscopic whiskers of nonconductive, electrochemically stable perylene red (PR) pigment, thus forming a hydrophilic 
nano-structured thin film (NSTF) catalyst for the water electrolyzer anode [24, 64-67]. This whisker-like catalyst material can be laminated and imbedded into the ion exchange membrane of solid polymer electrolyte electrochemical cells, such as PEM water electrolyzers. The thin continuous metallic layer provides high conductivity and high mass-specific catalytic activity with low platinum group metal catalyst loading. The nonconductive perylene red substrate allows for high dispersion of catalytically active centers and at the same time avoids the carbon corrosion that occurs at OER potentials with carbon-supported catalysts. The combination offers catalyst stability typically associated with unsupported PGM blacks, while allowing for high electrochemical surface areas typical of supported catalysts.

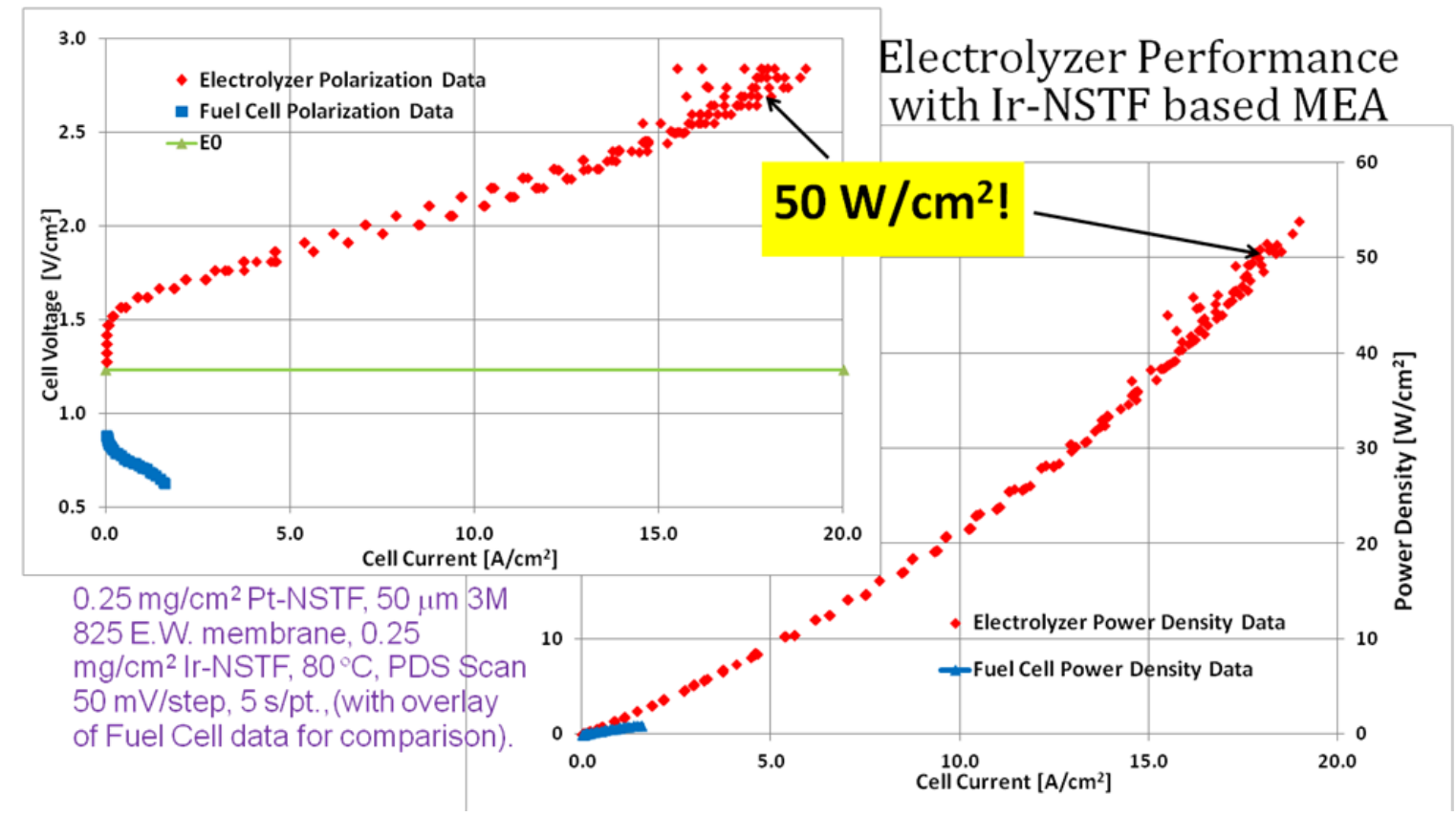

Figure 2 Example of NSTF based CCM in electrolyzer cell. The cell and operating conditions as indicated in the graph and experimental section (standard operating conditions), the anode Ir-NSTF catalyst is modified for high current operation. Data obtained at $80^{\circ} \mathrm{C}$ and ambient pressure.

Error! Reference source not found. shows a polarization curve and a power curve for a PEM water electrolyzer with $0.25 \mathrm{mg} / \mathrm{cm}^{2}$ of $\mathrm{IrO}_{2}$ on the anode and $0.25 \mathrm{mg} / \mathrm{cm}^{2}$ of platinum on the cathode at $80{ }^{\circ} \mathrm{C}$. Notice that the cell runs at about $8 \mathrm{~A} / \mathrm{cm}^{2}$ at a potential of $2 \mathrm{~V}$ (almost $75 \%$ efficiency based on higher heating value of hydrogen). By comparison, Rozain et al. [55] demonstrate currents of about $1.5 \mathrm{~A} / \mathrm{cm}^{2}$ at similar conditions, with $\mathrm{IrO}_{2}$ loadings of $1.5 \mathrm{mg} / \mathrm{cm}^{2}$. Skulimowska et al. [58] also report currents of $1.4 \mathrm{~A} / \mathrm{cm}^{2}$ at $\mathrm{IrO}_{2}$ loadings of $2 \mathrm{mg} / \mathrm{cm}^{2}$. Siracusano et al. $[56,57]$ find that heating the cell to $90{ }^{\circ} \mathrm{C}$ increases the current to $4 \mathrm{~A} / \mathrm{cm}^{2}$ at $\mathrm{IrO}_{2}$ loadings of $1.5 \mathrm{mg} / \mathrm{cm}^{2}$. Similarly, a recent paper by Rozain et al. [54] shows initial currents of $1.6 \mathrm{~A} / \mathrm{cm}^{2}$ at $\mathrm{IrO}_{2}$ loadings of $0.23 \mathrm{mg} / \mathrm{cm}^{2}$.

Notice that Error! Reference source not found. shows the highest current observed so far at a $2 \mathrm{~V}$ potential, and uses some of the lowest catalyst loadings. Further, the above described $\mathrm{H}_{2} \mathrm{O}$ electrolyzer is stable. An earlier version of the system using the more common Nafion 115 perfluorosulfonic acid based (PFSA) PEM membrane demonstrated 5000 hours of operation at current densities of $2 \mathrm{~A} / \mathrm{cm}^{2}$ (20,000 turnovers/sec) and cell voltages of about $1.85 \mathrm{~V}$ with an average voltage loss rate of only $6.8 \mu \mathrm{V} / \mathrm{h}$. This corresponds to about $3 \times 10^{11}$ total turnovers. 
We also have demonstrated current densities over $19 \mathrm{~A} / \mathrm{cm}^{2}$ and an operating power density in excess of $50 \mathrm{~W} / \mathrm{cm}^{2}$. To our knowledge this is the highest power density ever reported in a PEM electrolyzer.

\section{2 $\mathrm{CO}$ from electrochemical $\mathrm{CO}_{2}$ splitting}

$\mathrm{CO}_{2}$ has low solubility in acidic water solutions, which limits mass transport and reaction rates. In contrast, $\mathrm{CO}_{2}$ has high solubility in alkaline solutions, due to the reaction with hydroxides to form bicarbonates and carbonates, but these species tend to poison commercial anion exchange membranes, as discussed above. The authors have recently developed anion exchange membranes that have high anionic conductivity and good tolerance for the presence of bicarbonates from $\mathrm{CO}_{2}[13,14]$.

An early breakthrough, described in Rosen et al. [19], was the addition of an organic cationic co-catalyst, such as 1-ethyl-3-methyl imidazolium $\left(\mathrm{EMIM}^{+}\right)$, which forms a weak complex with $\mathrm{CO}_{2}$, thus reducing the overpotential for the rate-limiting step of transferring an electron from the negative electrode to $\mathrm{CO}_{2}$, as illustrated in Figure 3 .

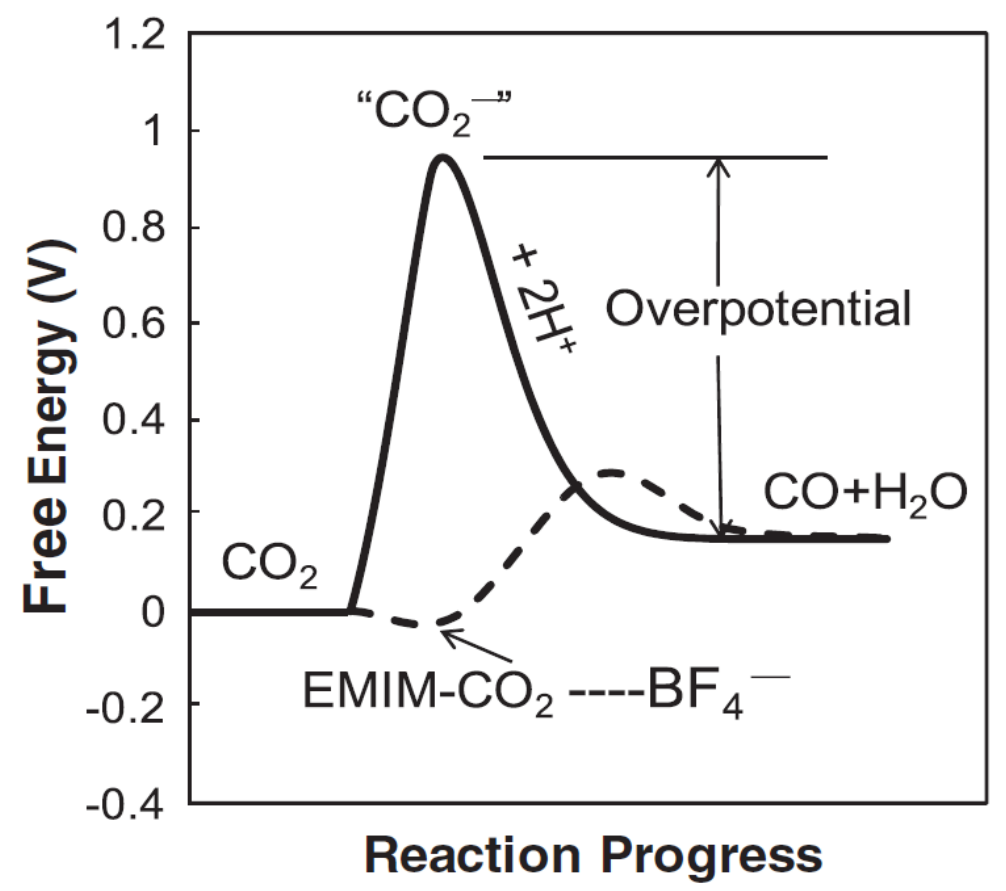

Figure $3 \mathrm{CO}_{2}$ reduction facilitated by weak $\mathrm{CO}_{2}-\mathrm{EMIM}^{+}$complex formation [19].

A further unexpected benefit is that certain "Helper Catalysts" like $\mathrm{EMIM}^{+}$(Fig. 3) appear to block access of hydronium (" $\mathrm{H}^{+}$") ions to the negative electrode, suppressing the normal hydrogen evolution reaction (HER) of water electrolysis [22, 23], and thus greatly increasing the selectivity toward $\mathrm{CO}$ production on silver catalysts. The competing cathode half-cell reactions are shown below. 


$$
\begin{aligned}
& \mathrm{CO}_{2}+\mathrm{H}_{2} \mathrm{O}+2 e^{-}=\mathrm{CO}+2 \mathrm{OH}^{-} \\
& \mathrm{CO}_{2}+2 \mathrm{H}^{+}+2 e^{-}=\mathrm{CO}+\mathrm{H}_{2} \mathrm{O} \\
& 2 \mathrm{H}^{+}+2 e^{-}=\mathrm{H}_{2}
\end{aligned}
$$

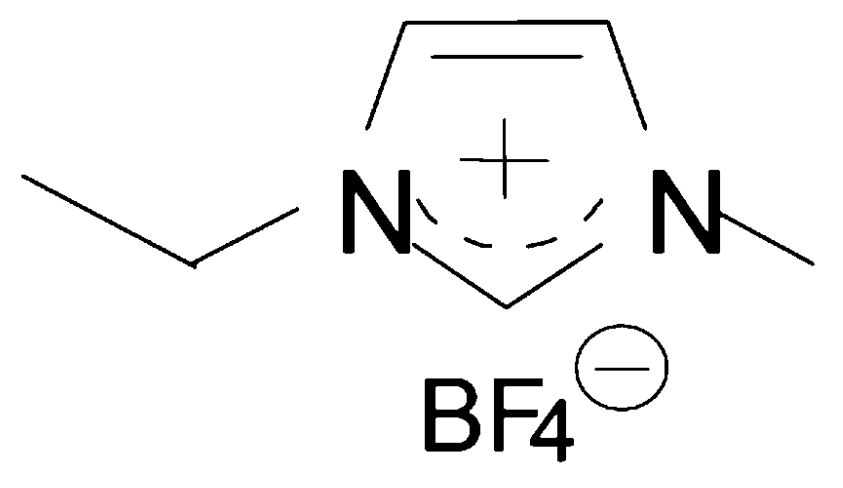

\section{$\mathrm{EMIM} \mathrm{BF}_{4}$}

Figure 4 1-ethyl-3-methyl imidazolium tetrafluoroborate $\left(\mathrm{EMIM}^{+} \mathrm{BF}_{4}{ }^{-}\right)$

The initial investigations described in our previous work [19] were conducted in liquid catholyte cells using the "ionic liquid" salt $\mathrm{EMIM}^{+} \mathrm{BF}_{4}{ }^{-}$(Figure 4) as the source of the EMIM" "Helper Catalyst" [11]. These systems showed an initial $98 \%$ selectivity toward CO product. However, the selectivity was found to decrease over time, apparently due to slow hydrolysis of the $\mathrm{BF}_{4}{ }^{-}$anion, which produced corrosive $\mathrm{HF}$ and made the catholyte more acidic. As a result, a series of alternative $\mathrm{EMIM}^{+}$salts with more hydrolytically stable anions were tested, as shown in Table 1.

Table 1 CO selectivity with different ionic liquids in $1 \mathrm{~cm}^{2}$ liquid cell

\begin{tabular}{lccc}
\hline Ionic liquids & $\begin{array}{c}\text { Current density/ } \\
\mathrm{mA} / \mathrm{cm}^{2}\end{array}$ & $\begin{array}{c}\text { CO Selectivity } \\
\%\end{array}$ & Notes \\
EMIM-Cl & 50 & 97.08 & Commercially available \\
EMIM-HSO & 50 & 12.22 & Commercially available \\
$(\text { EMIM })_{2} \mathrm{SO}_{4}$ & 50 & 95.39 & Synthesized in house \\
EMIM- $\mathrm{HCO}_{3}$ & 50 & 97.44 & Synthesized in house \\
EMIM- $\mathrm{H}_{2} \mathrm{PO}_{4}$ & 50 & 45.83 & Synthesized in house \\
\hline
\end{tabular}


The tests with the various anions showed that as the catholyte becomes more acidic, the higher concentration of $\mathrm{H}^{+}$increases the competing hydrogen evolution reaction, thus increasing the production of $\mathrm{H}_{2}$ and decreasing the selectivity toward $\mathrm{CO}$.

A study versus concentration of the Helper Catalyst EMIM-Cl in aqueous catholyte with a silver cathode catalyst demonstrated high selectivity over a wide range of concentrations, as shown in Figure 5. The baseline was a $50 \mathrm{wt} \%$ aqueous solution of EMIM-Cl, which has a concentration of approximately 3.6 M. Selectivity greater than 90\% was observed with 0.5-3.6 M EMIM-Cl. Slightly higher selectivity was observed at higher concentration and higher current. Since EMIM-Cl is noticeably more viscous than water, there appears to be a trade-off between viscosity (ion mobility) and ion concentration (number of charge carriers.)

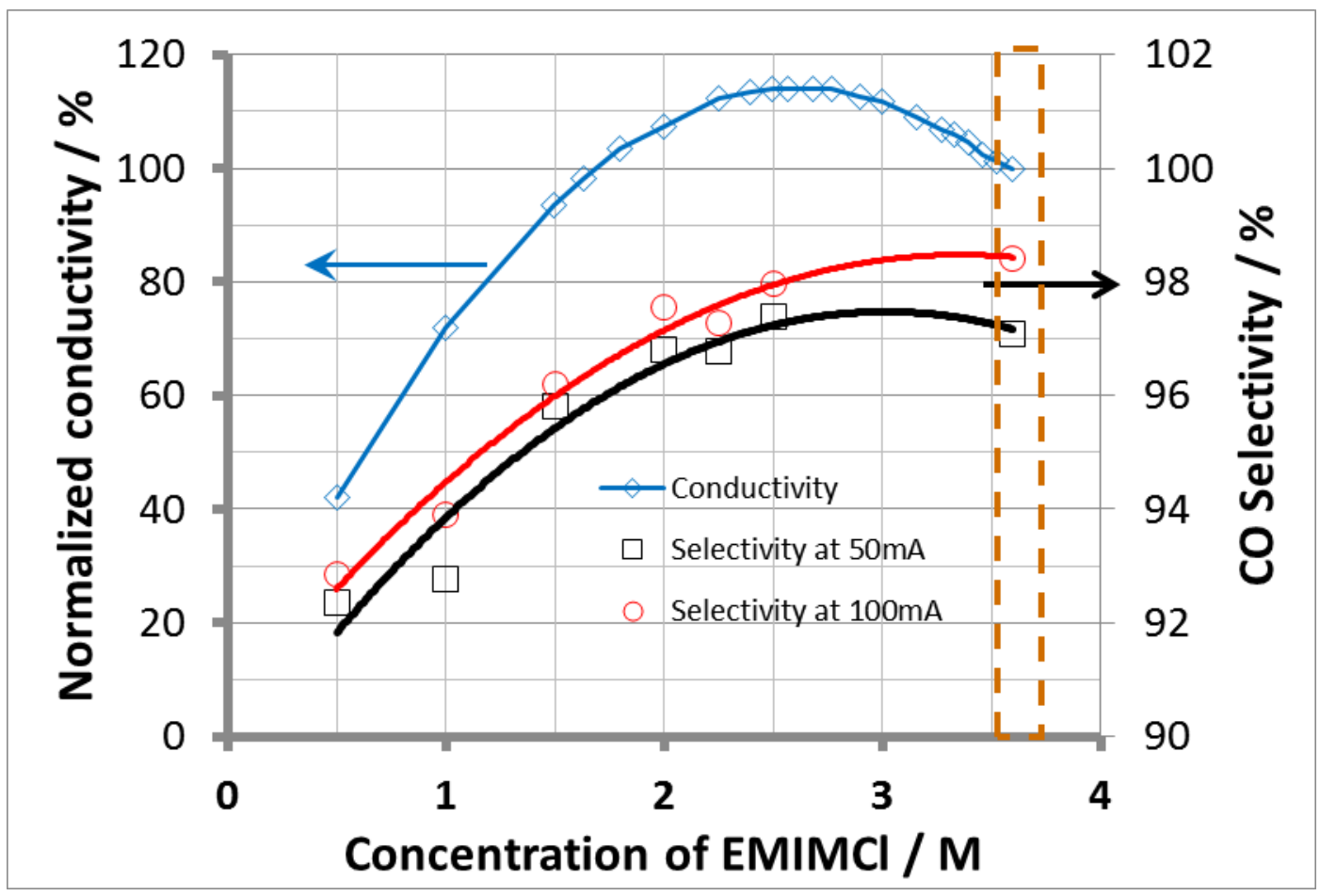

Figure 5 CO selectivity vs. concentration of EMIM-Cl[20]

\subsection{Direct syngas production from a single electrolyzer by tuning the pH of the catholyte}

As indicated above, the preferred $\mathrm{H}_{2} / \mathrm{CO}$ ratio for syngas is typically from $1 / 1$ to $4 / 1$, corresponding to a $\mathrm{CO}$ selectivity of $50 \%$ to $20 \%$. The study above using acidic $\mathrm{EMIM}^{+}$ counterions suggests that one way to tune the $\mathrm{CO}$ selectivity and $\mathrm{H}_{2} / \mathrm{CO}$ ratio of the reaction is to increase the acidity of the catholyte, thus increasing the rate of the hydrogen evolution reaction. The data in Table 2, in which the $\mathrm{pH}$ of an EMIM-Cl catholyte solution was adjusted by the addition of $\mathrm{HCl}$, shows this to be the case. However, the data at $\mathrm{pH}=1$ shows that it is necessary to control both the $\mathrm{pH}$ and the current density in order to keep the produced syngas mixture at the desired $\mathrm{H}_{2} / \mathrm{CO}$ ratio.

Table $250 \mathrm{wt} \%$ aqueous EMIM-Cl catholyte, $\mathrm{pH}$ adjusted by addition of $\mathrm{HCl}$

$\begin{array}{ccccc}\text { pH } & \text { Cathode Potential } & \begin{array}{c}\text { Current Density } \\ (\mathrm{mA})\end{array} & \begin{array}{c}\text { CO Selectivity } \\ (\%)\end{array} & \mathrm{H}_{2} / \mathrm{CO}\end{array}$




\begin{tabular}{ccccc}
\hline $\mathbf{6 . 6}$ & -1.2 & 25 & 99.1 & 0.009 \\
$\mathbf{2}$ & -1.34 & 25 & 98.2 & 0.02 \\
$\mathbf{1 . 5}$ & -1.34 & 25 & 98.7 & 0.01 \\
\hline $\mathbf{1 . 2}$ & -1.25 & 25 & 85.0 & 0.18 \\
$\mathbf{1 . 1}$ & -1.27 & 25 & 34.4 & 1.9 \\
$\mathbf{1 . 1}$ & -1.2 & 20 & 23.6 & 3.24 \\
$\mathbf{1 . 1}$ & -1.25 & 24 & 33.5 & 1.99 \\
$\mathbf{0 . 5}$ & -0.88 & 25 & 0.9 & 103.94 \\
$\mathbf{0 . 5}$ & -1.24 & 50 & 18.6 & 4.38 \\
\hline
\end{tabular}

\subsection{Switching to a solid electrolyte cell design}

While the initial development on the $\mathrm{CO}_{2}$ electrolyzer was done primarily using a Helper Catalyst like EMIM-Cl in a liquid catholyte [11, 16, 18-20, 23], this was accompanied by some problems, such as high cell resistance due to the electrolyte fluids, as well as occasional "flooding" of non-catalyst regions of the cathode carbon fiber paper gas diffusion layer with electrolyte, which increased hydrogen evolution and thus reduced the CO selectivity. A decision was made to switch to a solid electrolyte cathode cell, similar to the cells used in the PEM water electrolyzer described above $[13,14,16]$.

\subsection{Development of improved anion conducting membranes}

In the process of implementing a solid catholyte cell design, a series of proprietary new anion exchange membranes were developed [13, 14]. Cells using these membranes have demonstrated $\mathrm{CO}$ selectivities comparable to those achieved in the liquid catholyte cells, along with higher current densities and more stable performance. Some examples are shown in Table 3 below. A current density of $100 \mathrm{~mA} / \mathrm{cm}^{2}$ at a cell voltage of $3 \mathrm{~V}$ was achieved with membrane DX4-13, and $300 \mathrm{~mA} / \mathrm{cm}^{2}$ was demonstrated at $2.8 \mathrm{~V}$ with DX5-13. In all cases the selectivity was above $90 \%$ at $3 \mathrm{~V}$ potential.

By comparison, Aeshala, et al. [68] observe only about $20 \mathrm{~mA} / \mathrm{cm}^{2}$ and $25 \%$ selectivity at a similar potential, Delacourt et al. [69] observes only $20 \mathrm{~mA} / \mathrm{cm}^{2}$ and $60 \%$ selectivity, Genovese et al. [41, 70, 71] observe only $20 \mathrm{~mA} / \mathrm{cm}^{2}$ at $12 \%$ selectivity, and Media-Romos et al.[72] observe $25 \mathrm{~mA} / \mathrm{cm}^{2}$ and $80 \%$ efficiency in the presence of an imidazolium salt similar to the ones described in our patents.

Figure 6 shows stable selectivity and cell voltage over 250 hours of operation at 100 $\mathrm{mA} / \mathrm{cm}^{2}$ for one of these solid catholyte cells. At our catalyst loadings, a current of $100 \mathrm{~mA} / \mathrm{cm}^{2}$ corresponds to about 1100 turnovers/sec, and the data in Figure 6 corresponds to about 4 billion turnovers. In other runs we have run for up to 1000 hours, corresponding to about 15 billion turnovers.

Table 3. GC analysis of gas products from a $5 \mathrm{~cm}^{2}$ solid cell with anion exchange membrane. 
The current is the total current in the $5 \mathrm{~cm}^{2}$ cell.

\begin{tabular}{ccccc}
\hline anion exchange membrane & $\begin{array}{c}\text { Cell potential } \\
\text { (V) }\end{array}$ & $\begin{array}{c}\text { Current } \\
\text { (mA) }\end{array}$ & $\begin{array}{c}\text { CO selectivity } \\
\text { (\%) }\end{array}$ & H2/CO \\
\hline DX4-13 & 2.66 & 200 & 79.9 & 0.252 \\
DX4-13 & 2.75 & 300 & 91.4 & 0.094 \\
DX4-13 & 2.97 & 500 & 92.3 & 0.084 \\
DX5-13 & 2.80 & 1500 & 93.8 & 0.066 \\
\hline
\end{tabular}

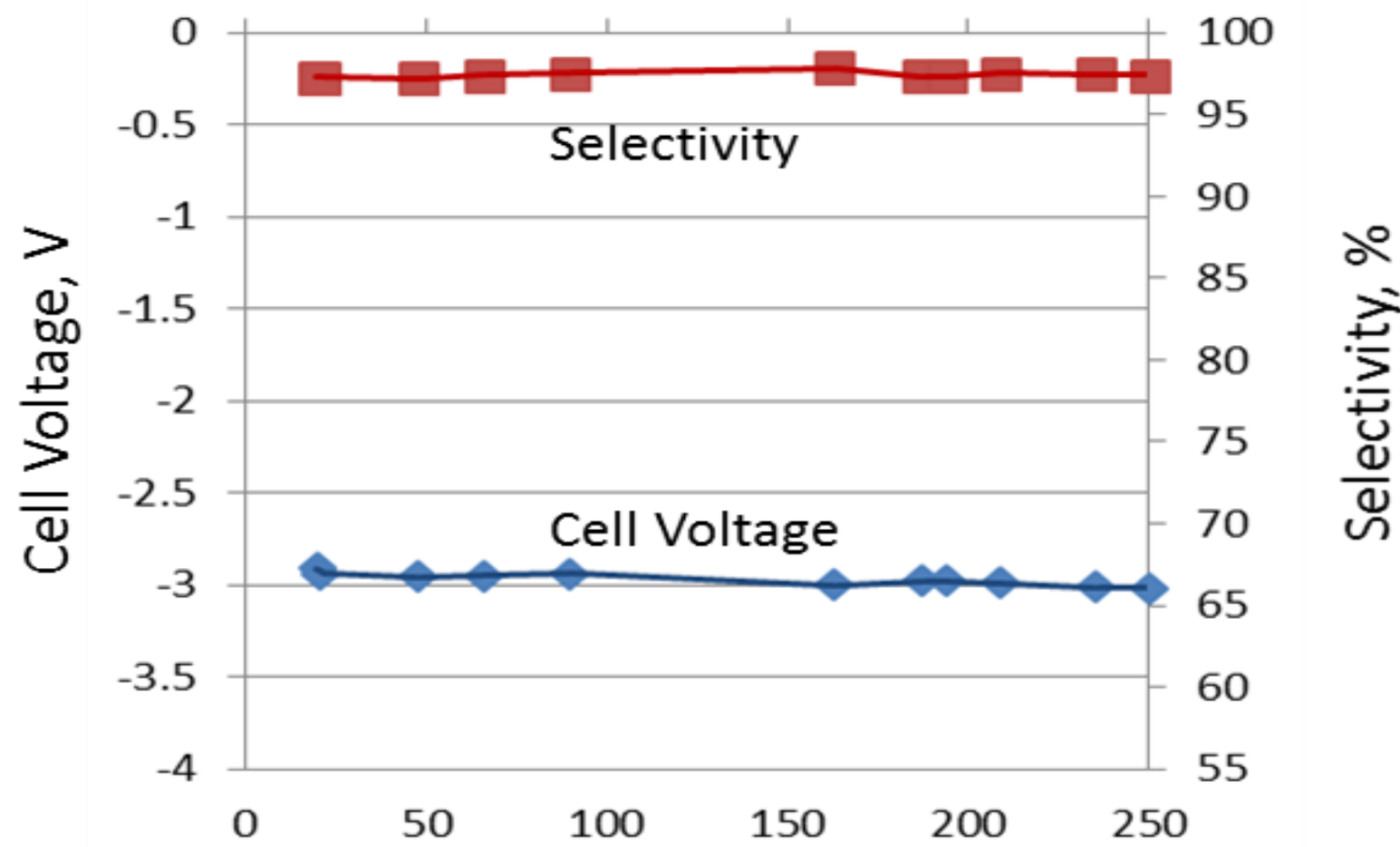

Time, Hours

Figure 6 Stable operation of a solid catholyte cell over 250 hours.

\subsection{Producing syngas in a solid catholyte cell - bimetallic catalysts}

One approach to directly producing a syngas mixture from a single cell would be to use two electrocatalyst metals on the cathode, one for each of the desired reactions. Ag catalyzes reduction of $\mathrm{CO}_{2}$ to $\mathrm{CO}$, while $\mathrm{Ni}$ and $\mathrm{Pt}$ promote hydrogen evolution. $\mathrm{Ni}$ is a good catalyst for the HER in neutral or alkaline media, while Pt catalysts are easily poisoned by the $\mathrm{CO}$, so $\mathrm{Ni}$ is the logical choice. Table 4 shows the results from using a cathode catalyst ink containing various ratios of $\mathrm{Ag} / \mathrm{Ni}$ nanoparticles. As the table shows, a syngas mixture in the desired composition range was obtained with an $\mathrm{Ag} / \mathrm{Ni}$ ratio of $1 / 4$ and a cell voltage of $3 \mathrm{~V}$. The 
reported current is the total current in a $5 \mathrm{~cm}^{2}$ membrane cell.

Table 4. GC analysis of gas products from a $5 \mathrm{~cm}^{2}$ solid cell using Ag/Ni bimetallic catalysts.

\begin{tabular}{ccccc}
\hline Ag/Ni ratio & current $(\mathrm{mA})$ & Cell potential $(\mathrm{V})$ & $\mathrm{CO}$ selectivity $(\%)$ & $\mathrm{H}_{2} / \mathrm{CO}$ \\
\hline $0 / 1$ & 100 & 2.7 & 0.00 & \\
& 200 & 3 & 0.00 & \\
$1 / 2$ & 200 & 2.8 & 52.61 & 0.90 \\
& 300 & 3.1 & 52.63 & 0.90 \\
\multirow{2}{*}{$1 / 4$} & 200 & 2.8 & 18.85 & 4.30 \\
& 300 & 3 & 37.01 & 1.70 \\
\hline
\end{tabular}

\subsection{Syngas production by tuning the $\mathrm{pH}$ at the cathode/membrane interface}

In the examples described above, the anode half-cell reaction was typically the "water splitting" oxygen evolution reaction (OER.) Deionized water was typically supplied to the anode. (Humidified $\mathrm{CO}_{2}$ gas was provided to the cathode, to prevent dry out of the membrane.) However, circulating a sulfuric acid solution on the anode side of the anion exchange membrane was found to influence the $\mathrm{pH}$ on the cathode side of the membrane, thus increasing the HER and decreasing the $\mathrm{CO}$ selectivity into the desired syngas range of $20-50 \%$. In theory, anions migrate from cathode to anode through an anion exchange membrane in an electrolyzer, while cations transport from anode to cathode if cations are present at the anode. Here we fed $\mathrm{H}_{2} \mathrm{SO}_{4}$ to the anode so that protons could diffuse to the cathode, thus tuning the $\mathrm{pH}$ of the cathode/membrane interface and producing syngas. An example is shown below in Figure 7. A current density of $100 \mathrm{~mA} / \mathrm{cm}^{2}$ was applied to the cell. With $0.1 \mathrm{M} \mathrm{H}_{2} \mathrm{SO}_{4}$ at the anode, the selectivity was still as high as $90 \%$. Further increasing the concentration of $\mathrm{H}_{2} \mathrm{SO}_{4}$ to $0.3 \mathrm{M}$, the selectivity decreased to $40 \%$. The selectivity was quite stable at each concentration.

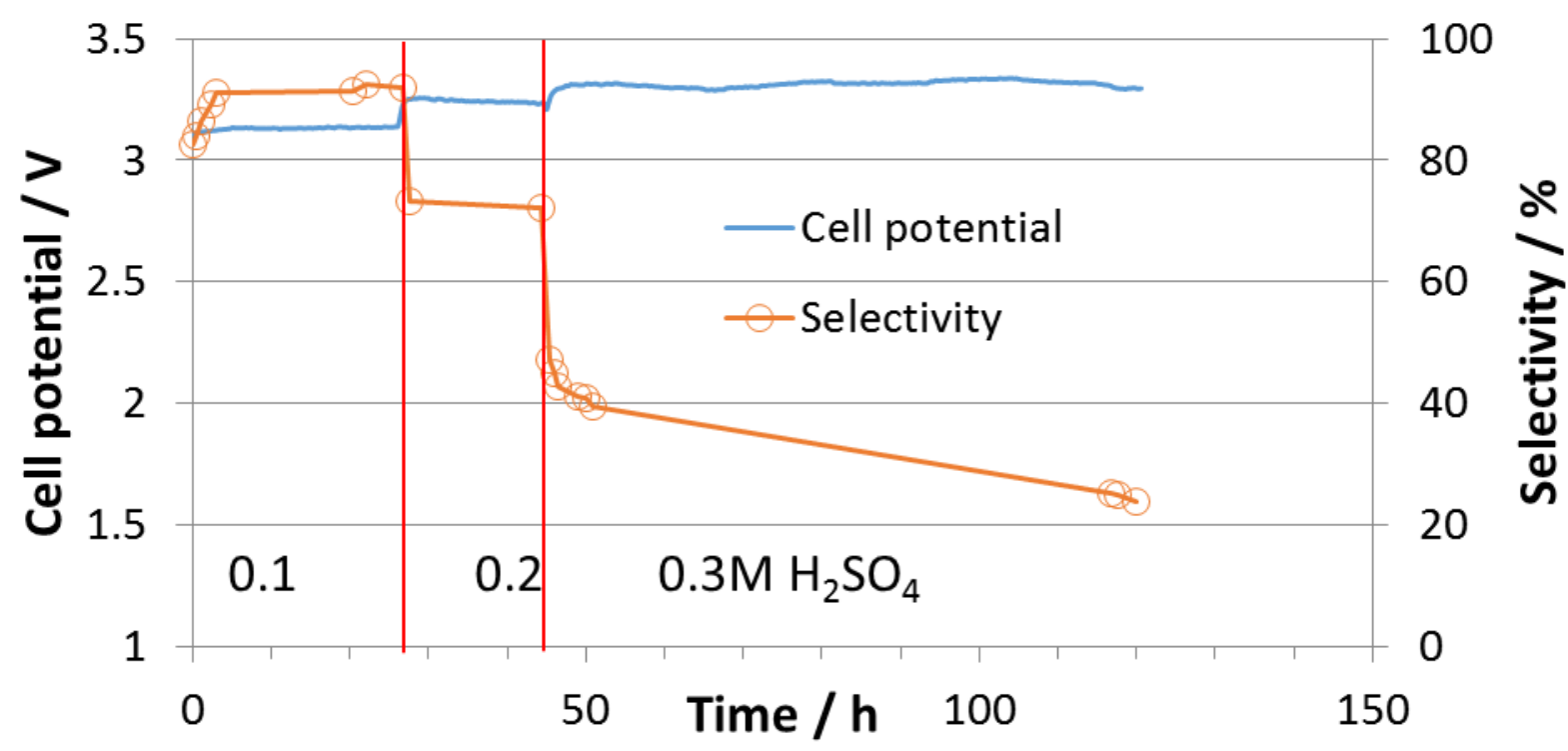


Figure 7 Adjusting syngas composition by acidifying the anode side of the anion exchange membrane.

\section{SUMMARY}

In this review we have explored the recent technologies that enable the production of syngas at industrially relevant rates. These technologies support two strategies for syngas production: the tandem production of $\mathrm{H}_{2}$ and $\mathrm{CO}$ in separate electrolyzers, and the simultaneous production of $\mathrm{H}_{2}$ and $\mathrm{CO}$ at a fixed ratio in a single electrolyzer.

The authors have shown that concomitant use of novel NSTF catalysts and PEMs allows for water electrolysis at extremely high current densities. Additionally, the use of ionic liquid cocatalysts for highly selective reduction of $\mathrm{CO}_{2}$ to $\mathrm{CO}$ strongly suppressed the hydrogen evolution reaction. Eventually this $\mathrm{CO}_{2}$ reduction technology eschewed the ionic liquids in order to operate in the present leaner and more efficient solid-state design that employs a novel anion-exchange membrane. If these two technologies were to operate in two tandem electrolyzers, this would permit the mixing of their output gases at any desired ratio as a way of generating syngas.

If it is more advantageous to the intended application for syngas to be efficiently produced in a single electrolyzer, then the technologies that the authors have demonstrated also enable this. The authors have shown that the careful manipulation of the $\mathrm{pH}$ on either side of the anion exchange membrane, as well as the use of bimetallic catalysts on the cathode, both permit highcapacity syngas generation at the desired $\mathrm{CO}$ percentage range.

The electrolyzer technologies presented here are capable of running at industrially-relevant current densities of $100 \mathrm{~mA} / \mathrm{cm}^{2}$ and often higher. Furthermore, repeated tests have shown longterm performance of these systems with negligible degradation or loss of function in the novel components such as the anion-exchange membrane. Our ambition is that these efficient and robust technologies will enable high-volume syngas generation in a variety of applications.

\section{ACKNOWLEDGEMENTS}

Parts of this work were supported by the U.S. Air Force under contract FA8650-14-C-2417, ARPA-E under contract DE-AR0000345, NASA under contract NNX12CE73P, DOE under contracts DE-SC0004192 and DE-SC0007471, and 3M Company. The opinion are those of the authors and may not reflect the opinions of the USAF, NASA, DOE or ARPA-E. Special thanks to Tyler S. Matthews, Matthew Quast, and Nancy Kunz of 3M for help in preparing and testing materials and membranes. Assistance from other colleagues, collaborators and friends from 3M, Giner, Inc., HySA, NREL, and Proton OnSite is also gratefully acknowledged.

\section{LITERATURE CITED}

[1]. Assen, N.v.d., A. Sternberg, A. Kaetelhoen, and A. Bardow, Environmental Potential of Carbon Dioxide Utilization in the Polyurethane Supply Chain. Faraday Discuss., 2015, 183, pp. 291-307.

[2]. Damiani, D., J.T. Litynski, H.G. McIlvried, and D.M. Vikara, The US Department of Energy's R\&D Program to Reduce Greenhouse Gas Emissions through Beneficial Uses 
of Carbon Dioxide. Greenhouse Gases: Sci. Technol., 2012. 2: p. 9-19.

[3]. Dimitriou, I., P. Garcia-Gutierrez, R.H. Elder, R.M. Cuellar-Franca, A. Azapagic, and R.W.K. Allen, Carbon Dioxide Utilisation for Production of Transport Fuels: Process and Economic Analysis. Energy Environ. Sci., 2015. 8: p. 1775-1789.

[4]. Dumont, M.-N., N. von der Assen, A. Sternberg, and A. Bardow, Assessing the Environmental Potential of Carbon Dioxide Utilization: A Graphical Targeting Approach. Comput.-Aided Chem. Eng., 2012. 31: p. 1407-1411.

[5]. Kondratenko, E.V., G. Mul, J. Baltrusaitis, G.O. Larrazabal, and J. Perez-Ramirez, Status and Perspectives of $\mathrm{CO}_{2}$ Conversion into Fuels and Chemicals by Catalytic, Photocatalytic and Electrocatalytic Processes. Energy Environ. Sci., 2013. 6: p. 31123135.

[6]. Lively, R.P., P. Sharma, B.A. McCool, J. Beaudry-Losique, D. Luo, V.M. Thomas, M. Realff, and R.R. Chance, Anthropogenic $\mathrm{CO}_{2}$ as a Feedstock for the Production of AlgalBased Biofuels. Biofuels, Bioprod. Biorefin., 2015. 9: p. 72-81.

[7]. Milani, D., R. Khalilpour, G. Zahedi, and A. Abbas, A Model-Based Analysis of $\mathrm{CO}_{2}$ Utilization in Methanol Synthesis Plant. J. $\mathrm{CO}_{2}$ Util., 2015. 10: p. 12-22.

[8]. Olajire, A.A., Valorization of Greenhouse Carbon Dioxide Emissions into Value-Added Products by Catalytic Processes. J. $\mathrm{CO}_{2}$ Util., 2013. 3-4: p. 74-92.

[9]. Otto, A., T. Grube, S. Schiebahn, and D. Stolten, Closing the Loop: Captured $\mathrm{CO}_{2}$ as a Feedstock in the Chemical Industry. Energy Environ. Sci., 2015, 8 (11), pp. 3283-3297.

[10]. Masel, R.I., Z. Liu, D. Zhao, Q. Chen, D. Lutz, and L. Nereng, $\mathrm{CO}_{2}$ Conversion to Chemicals with Emphasis on Using Renewable Energy/Resources to Drive the Conversion, in Commercializing Biobased Products: Opportunities, Challenges, Benefits, and Risks, S.W. Snyder, Editor 2016, Royal Society of Chemistry: Cambridge. p. 215257.

[11]. Masel, R.I., Novel Catalyst Mixtures, U.S. Patent 8,956,990 (2014).

[12]. Masel, R.I. and Q. Chen, Carbon Dioxide Conversion to Fuels and Chemcials, U.S. Patent 9,193,593 (2015).

[13]. Masel, R.I., Q. Chen, Z. Liu, and R. Kutz, Ion-Conducting Membranes, U.S. Patent Application 14/704935 (2014).

[14]. Masel, R.I., Q. Chen, Z. Liu, and R. Kutz, Carbon Dioxide Electrolyzer, U.S. Patent Application 14/704934 (2014).

[15]. Masel, R.I., R. Ni, Z. Liu, Q. Chen, R. Kutz, L. Nereng, D. Lutz, and K. Lewinski, Unlocking the Potential of $\mathrm{CO}_{2}$ Conversion to Fuels and Chemicals as an Economically Viable Route to CCR. Energy Procedia, 2014. 63: p. 7959-7962.

[16]. Masel, R.I., B.A. Rosen, and W. Zhu, Devices and Processes for Carbon Dioxide Conversion into Useful Fuels and Chemicals, U.S. Patent 9,181,625 (2014).

[17]. Masel, R.I., A. Salahi-Khogin, and B. Rosen, Catalysts for Electrochemical Conversion of Carbon Dioxide, U.S. Patent 9,012,345 (2015).

[18]. Rosen, B.A., J.L. Haan, P. Mukherjee, B. Braunschweig, W. Zhu, A. Salehi-Khojin, D.D. Dlott, and R.I. Masel, In Situ Spectroscopic Examination of a Low Overpotential Pathway for Carbon Dioxide Conversion to Carbon Monoxide. J. Phys. Chem. C, 2012. 116: p. 15307-15312.

[19]. Rosen, B.A., A. Salehi-Khojin, M.R. Thorson, W. Zhu, D.T. Whipple, P.J.A. Kenis, and R.I. Masel, Ionic Liquid Mediated Selective Conversion of $\mathrm{CO}_{2}$ to $\mathrm{CO}$ at Low Overpotentials. Science, 2011. 334 p. 643-644. 
[20]. Rosen, B.A., W. Zhu, G. Kaul, A. Salehi-Khojin, and R.I. Masel, Water Enhancement of $\mathrm{CO}_{2}$ Conversion on Silver in 1-Ethyl-3-Methylimidazolium Tetrafluoroborate. Journal of the Electrochemical Society, 2013. 160: p. H138-H141.

[21]. Salehi-Khojin, A., H.-R.M. Jhong, B.A. Rosen, W. Zhu, S. Ma, P.J.A. Kenis, and R.I. Masel, Nanoparticle Silver Catalysts That Show Enhanced Activity for Carbon Dioxide Electrolysis. J. Phys. Chem. C, 2013. 117: p. 1627-1632.

[22]. Zhu, W., B.A. Rosen, A. Salehi-Khojin, and R.I. Masel, Monolayers of Choline Chloride Can Enhance Desired Electrochemical Reactions and Inhibit Undesirable Ones. Electrochimica Acta, 2013. 96: p. 18-22.

[23]. Masel, R.I. Novel Catalyst Mixtures, U.S. Patent Application 2012-0308903 (2012).

[24]. Debe, M.K., S.M. Hendricks, G.D. Vernstrom, M. Meyers, M. Brostrom, M. Stephens, Q. Chan, J. Willey, M. Hamden, C.K. Mittelsteadt, C.B. Capuano, K.E. Ayers, and E.B. Anderson, Initial Performance and Durability of Ultra-Low Loaded NSTF Electrodes for PEM Electrolyzers. J. Electrochem. Soc., 2012. 159: p. K165-K176.

[25]. Lewinski, K.A. and S.M. Luopa, Oxygen Evolution Catalyst Electrodes, Provisional U.S. Patent Application 62/166471 (2015).

[26]. Lewinski, K.A., D.v.d. Vliet, and S.M. Luopa, NSTF Advances for PEM Electrolysis - the Effect of Alloying on Activity of NSTF Electrolyzer Catalysts and Performance of NSTF Based PEM Electrolyzers/Electrocatalysis in Electrolysis Applications. ECS Trans., 2015. 69: p. 893-917.

[27]. Van Der Laan, G.P. and A. Beenackers, Kinetics and Selectivity of the Fischer-Tropsch Synthesis: A Literature Review. Catalysis Reviews, 1999. 41: p. 255-318.

[28]. Ayers, K.E., E.B. Anderson, C.B. Capuano, B.D. Carter, L.T. Dalton, G. Hanlon, J. Manco, and M. Niedzwiecki, Research Advances Towards Low Cost, High Efficiency PEM Electrolysis. ECS Trans., 2010. 33: p. 3-15.

[29]. Ayers, K.E., C.B. Capuano, and E.B. Anderson, Recent Advances in Cell Cost and Efficiency for PEM-Based Water Electrolysis. ECS Trans., 2012. 41: p. 15-22.

[30]. Nguyen, V.N. and L. Blum, Syngas and Synfuels from $\mathrm{H}_{2} \mathrm{O}$ and $\mathrm{CO}_{2}$ : Current Status. Chem. Ing. Tech., 2015. 87: p. 354-375.

[31]. Liu, Q., L. Wu, R. Jackstell, and M. Beller, Using Carbon Dioxide as a Building Block in Organic Synthesis. Nat Commun, 2015. 6: p. 5933.

[32]. Kang, P., Z. Chen, M. Brookhart, and T.J. Meyer, Electrocatalytic Reduction of Carbon Dioxide: Let the Molecules Do the Work. Top. Catal., 2015. 58: p. 30-45.

[33]. Bevilacqua, M., J. Filippi, H.A. Miller, and F. Vizza, Recent Technological Progress in $\mathrm{CO}_{2}$ Electroreduction to Fuels and Energy Carriers in Aqueous Environments. Energy Technology, 2015. 3: p. 197-210.

[34]. Uhm, S. and Y.D. Kim, Electrochemical Conversion of Carbon Dioxide in a Solid Oxide Electrolysis Cell. Current Applied Physics, 2014. 14: p. 672-679.

[35]. Qiao, J., Y. Liu, F. Hong, and J. Zhang, A Review of Catalysts for the Electroreduction of Carbon Dioxide to Produce Low-Carbon Fuels. Chem Soc. Rev., 2014. 43: p. 631-75.

[36]. Lim, R.J., M. Xie, M.A. Sk, J.-M. Lee, A. Fisher, X. Wang, and K.H. Lim, A Review on the Electrochemical Reduction of $\mathrm{CO}_{2}$ in Fuel Cells, Metal Electrodes and Molecular Catalysts. Catal. Today, 2014. 233: p. 169-180.

[37]. Jones, J.-P., G.K.S. Prakash, and G.A. Olah, Electrochemical $\mathrm{CO}_{2}$ Reduction: Recent Advances and Current Trends. Isr. J. Chem., 2014. 54: p. 1451-1466.

[38]. Goeppert, A., M. Czaun, J.-P. Jones, G.K. Surya Prakash, and G.A. Olah, Recycling of 
Carbon Dioxide to Methanol and Derived Products - Closing the Loop. Chem. Soc. Rev., 2014. 43: p. 7995-8048.

[39]. Dibenedetto, A., A. Angelini, and P. Stufano, Use of Carbon Dioxide as Feedstock for Chemicals and Fuels: Homogeneous and Heterogeneous Catalysis. J. Chem. Technol. Biotechnol., 2014. 89: p. 334-353.

[40]. Kondratenko, E.V., G. Mul, J. Baltrusaitis, G.O. Larrazabal, and J. Perez-Ramirez, Status and Perspectives of $\mathrm{CO}_{2}$ Conversion into Fuels and Chemicals by Catalytic, Photocatalytic and Electrocatalytic Processes. Energy Environ. Sci., 2013. 6: p. 31123135.

[41]. Genovese, C., C. Ampelli, S. Perathoner, and G. Centi, Electrocatalytic Conversion of $\mathrm{CO}_{2}$ to Liquid Fuels Using Nanocarbon-Based Electrodes. J. Energy Chem., 2013. 22: p. 202-213.

[42]. Inglis, J.L., B.J. MacLean, M.T. Pryce, and J.G. Vos, Electrocatalytic Pathways Towards Sustainable Fuel Production from Water and $\mathrm{CO}_{2}$. Coord. Chem. Rev., 2012. 256: p. 2571-2600.

[43]. Boddien, A., F. Gaertner, C. Federsel, I. Piras, H. Junge, R. Jackstell, and M. Beller. Catalytic Utilization of Carbon Dioxide: Actual Status and Perspectives. 2012. WileyVCH Verlag GmbH \& Co. KGaA.

[44]. Srinivas, D., Carbon Dioxide to Chemicals and Fuels: Green Synthetic Approach. Chem. Ind. Dig., 2011. 24: p. 68-73.

[45]. Olah, G.A., G.K.S. Prakash, and A. Goeppert, Anthropogenic Chemical Carbon Cycle for a Sustainable Future. J. Am. Chem. Soc., 2011. 133: p. 12881-12898.

[46]. Whipple, D.T. and P.J.A. Kenis, Prospects of $\mathrm{CO}_{2}$ Utilization Via Direct Heterogeneous Electrochemical Reduction. J. Phys. Chem. Lett., 2010. 1: p. 3451-3458.

[47]. Hori, Y., Electrochemical $\mathrm{CO}_{2}$ Reduction on Metal Electrodes. Modern Aspects of Electrochemistry, 2008. 42: p. 89-189.

[48]. Gattrell, M., N. Gupta, and A. Co, A Review of the Aqueous Electrochemical Reduction of $\mathrm{CO}_{2}$ to Hydrocarbons at Copper. Journal of Electroanalytical Chemistry, 2006. 594: p. $1-19$.

[49]. DuBois, D.L., Carbon. Electrochemical Reactions of Carbon Dioxide. Encyclopedia of Electrochemistry, 2006. 7a: p. 202-225.

[50]. Goetz, M., J. Lefebvre, F. Moers, A. McDaniel Koch, F. Graf, S. Bajohr, R. Reimert, and T. Kolb, Renewable Power-to-Gas: A Technological and Economic Review. Renewable Energy, 2016. 85: p. 1371-1390.

[51]. Aresta, M., A. Dibenedetto, and A. Angelini, From $\mathrm{CO}_{2}$ to Chemicals, Materials and Fuels: The Role of Catalysis, Encyclopedia of Inorganic and Bioinorganic Chemistry, 2014.

[52]. Aresta, M., A. Dibenedetto, and A. Angelini, From $\mathrm{CO}_{2}$ to Chemicals and Fuels, Chem. Rev., 2014. 114: p. 1709-1742.

[53]. DuBois, D.L., Development of Molecular Electrocatalysts for Energy Storage, Inorg. Chem., 2014. 53: p. 3935-3960.

[54]. Rozain, C., E. Mayousse, N. Guillet, and P. Millet, Influence of Iridium Oxide Loadings on the Performance of PEM Water Electrolysis Cells: Part I-Pure IrO2-Based Anodes. Applied Catalysis B: Environmental, 2016. 182: p. 153-160.

[55]. Rozain, C. and P. Millet, Electrochemical Characterization of Polymer Electrolyte Membrane Water Electrolysis Cells. Electrochimica Acta, 2014. 131: p. 160-167. 
[56]. Siracusano, S., V. Baglio, E. Moukheiber, L. Merlo, and A.S. Aricò, Performance of a PEM Water Electrolyser Combining an IrRu-Oxide Anode Electrocatalyst and a ShortSide Chain Aquivion Membrane. International Journal of Hydrogen Energy, 2015. 40: p. 14430-14435.

[57]. Siracusano, S., N. Van Dijk, E. Payne-Johnson, V. Baglio, and A.S. Aricò, Nanosized $\mathrm{IrO}_{x}$ and $\operatorname{IrRuO}_{x}$ Electrocatalysts for the $\mathrm{O}_{2}$ Evolution Reaction in PEM Water Electrolysers. Applied Catalysis B: Environmental, 2015. 164: p. 488-495.

[58]. Skulimowska, A., M. Dupont, M. Zaton, S. Sunde, L. Merlo, D.J. Jones, and J. Rozière, Proton Exchange Membrane Water Electrolysis with Short-Side-Chain Aquivion ${ }^{\circledR}$ Membrane and $\mathrm{IrO}_{2}$ Anode Catalyst. International Journal of Hydrogen Energy, 2014. 39: p. 6307-6316.

[59]. Brushett, F.R., R.S. Jayashree, W.-P. Zhou, and P.J.A. Kenis, Investigation of Fuel and Media Flexible Laminar Flow-Based Fuel Cells. Electrochimica Acta, 2009. 54: p. 70997105.

[60]. Whipple, D.T., E.C. Finke, and P.J.A. Kenis, Microfluidic Reactor for the Electrochemical Reduction of Carbon Dioxide: The Effect of pH. Electrochemical and Solid-State Letters, 2010. 13: p. B109-B111.

[61]. Carmo, M., D.L. Fritz, J. Mergel, and D. Stolten, A Comprehensive Review on PEM Water Electrolysis. International Journal of Hydrogen Energy, 2013. 38: p. 4901-4934.

[62]. Siracusano, S., V. Baglio, F. Lufrano, P. Staiti, and A.S. Aricò, Electrochemical Characterization of a PEM Water Electrolyzer Based on a Sulfonated Polysulfone Membrane. Journal of Membrane Science, 2013. 448: p. 209-214.

[63]. Balaji, R., N. Senthil, S. Vasudevan, S. Ravichandran, S. Mohan, G. Sozhan, S. Madhu, J. Kennedy, S. Pushpavanam, and M. Pushpavanam, Development and Performance Evaluation of Proton Exchange Membrane (PEM) Based Hydrogen Generator for Portable Applications. International Journal of Hydrogen Energy, 2011. 36: p. 13991403.

[64]. Debe, M.K., Electrocatalyst Approaches and Challenges for Automotive Fuel Cells. Nature (London, U. K.), 2012. 486: p. 43-51.

[65]. Debe, M.K., Nanostructured Thin Film Electrocatalysts for PEM Fuel Cells - a Tutorial on the Fundamental Characteristics and Practical Properties of NSTF Catalysts. ECS Trans., 2012. 45: p. 47-68.

[66]. Debe, M.K., Tutorial on the Fundamental Characteristics and Practical Properties of Nanostructured Thin Film (NSTF) Catalysts. J. Electrochem. Soc., 2013. 160: p. F522F534.

[67]. van der Vliet, D.F., C. Wang, D. Tripkovic, D. Strmcnik, X.F. Zhang, M.K. Debe, R.T. Atanasoski, N.M. Markovic, and V.R. Stamenkovic, Mesostructured Thin Films as Electrocatalysts with Tunable Composition and Surface Morphology. Nat. Mater., 2012. 11: p. 1051-1058.

[68]. Aeshala, L.M., R. Uppaluri, and A. Verma, Electrochemical Conversion of $\mathrm{CO}_{2}$ to Fuels: Tuning of the Reaction Zone Using Suitable Functional Groups in a Solid Polymer Electrolyte. Physical Chemistry Chemical Physics, 2014. 16: p. 17588-17594.

[69]. Delacourt, C., P.L. Ridgway, J.B. Kerr, and J. Newman, Design of an Electrochemical Cell Making Syngas $\left(\mathrm{CO}+\mathrm{H}_{2}\right)$ from $\mathrm{CO}_{2}$ and $\mathrm{H}_{2} \mathrm{O}$ Reduction at Room Temperature. Journal of the Electrochemical Society, 2008. 155: p. B42-B49.

[70]. Genovese, C., C. Ampelli, S. Perathoner, and G. Centi, A Gas-Phase Electrochemical 
Reactor for Carbon Dioxide Reduction Back to Liquid Fuels. AIDIC CONFERENCE SERIES, 2013. 11: p. 151-160.

[71]. Genovese, C., C. Ampelli, S. Perathoner, and G. Centi, Electrocatalytic Conversion of $\mathrm{CO}_{2}$ on Carbon Nanotube-Based Electrodes for Producing Solar Fuels. J. Catal., 2013. 308: p. 237-249.

[72]. Medina-Ramos, J., J.L. DiMeglio, and J. Rosenthal, Efficient Reduction of $\mathrm{CO}_{2}$ to $\mathrm{CO}$ with High Current Density Using in Situ or Ex Situ Prepared Bi-Based Materials. Journal of the American Chemical Society, 2014. 136: p. 8361-8367. 


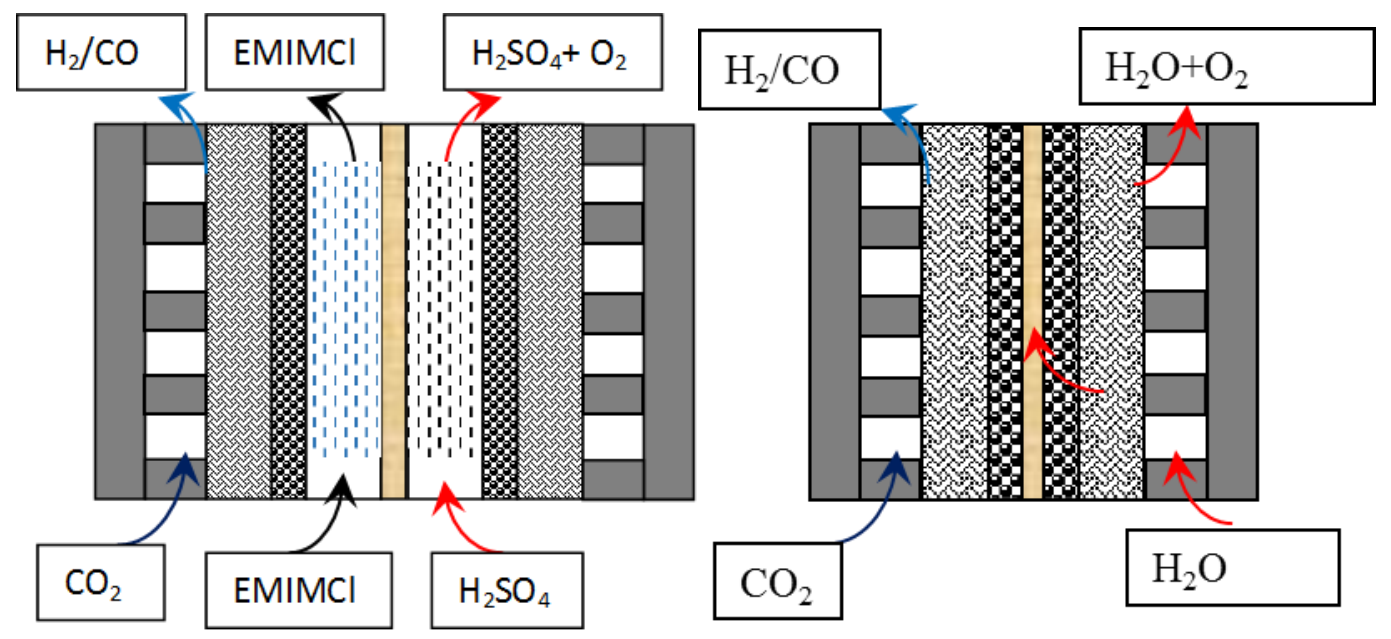

